\title{
Does college level the playing field? Socioeconomic gaps in the earnings of similar graduates: evidence from South Korea
}

\author{
Sangwoo Lee ${ }^{1}$ (D) Anna Vignoles ${ }^{1}$
}

Accepted: 22 July 2021 / Published online: 13 August 2021

(C) The Author(s) 2021

\begin{abstract}
The socioeconomic gap in participation at university is an enduring policy issue in South Korea, as in many other countries. However, less attention has been paid to the socioeconomic gap in the outcomes from tertiary education. This paper addresses this gap in the literature, using the Korean Education and Employment Panel (KEEP) data to investigate the extent to which the wages of Korean graduates who attended similar higher education institutions vary by socioeconomic background. The results show that a degree appears to largely level the playing field, in terms of earnings, between male graduates from poor and rich backgrounds. For females, by contrast, family background is still a strong predictor of earnings, even after allowing for institution attended and discipline of degree. Further, the wage premium for 2-year and 4-year college degrees also varies by family background. Four-year college degrees, contrary to popular belief, do not always attract a higher wage premium than 2-year college degrees, particularly for men from poorer family backgrounds.
\end{abstract}

Keywords Socioeconomic gaps $\cdot$ Graduate earnings $\cdot$ Wage premium $\cdot$ College type

\section{Introduction}

Traditionally, education has been highly valued in the Republic of Korea (hereafter South Korea). Most people are convinced that going to university, particularly one of the most prestigious universities, will guarantee good career prospects for any student (Cho, 2016). Participation in higher education is high, and approximately $70 \%$ of high school students in South Korea go to university (OECD, 2016). Certainly, up to the 1970s, individuals who went to university in South Korea (about $7 \%$ of the cohort at that time), regardless of their

Sangwoo Lee

s1947@cam.ac.uk

1 Faculty of Education, University of Cambridge, 184 Hills Rd, Cambridge CB2 8PQ, UK 
socioeconomic background, enjoyed a high return to their education (Kang, 2009; Kim \& Lee, 2006). Unfortunately, however, family income-related gaps both in access to and success in higher education are now large and even growing globally (Haveman \& Smeeding, 2006), and South Korea is no exception.

In South Korea, educational achievement and access to different types of higher education vary substantially by level of household income and/or assets, with fewer students from poorer backgrounds attending prestigious 4-year institutions (Choi \& Min, 2015; Jang, 1999). Despite this, many people still expect colleges and universities to ensure social mobility, and there is a strong meritocratic belief that higher education provides the opportunity for everyone with the right ability to succeed. An important policy question in South Korea is therefore whether higher education does in fact level the playing field, in terms of reducing or eliminating the disparity in earnings between individuals from high- and low-socioeconomic status backgrounds. Although much research and policy attention has been paid to the socioeconomic gap in university participation in South Korea, far less attention has been paid to the extent to which family background continues to impact graduates' earnings.

This paper, therefore, provides evidence on the socioeconomic gap in graduates' earnings, conditional on higher education institution attended and discipline choice, building on the limited literature on this issue from other country contexts (e.g., Britton et al., 2019; Chetty et al., 2017). Using the Korean Education and Employment Panel (KEEP) survey, provided by the Korea Research Institute for Vocational Education and Training (KRIVET), this paper addresses the following research questions: (a) is there a socioeconomic gap in the earnings of otherwise similar graduates? (b) How does the wage premium from different college types vary by individuals' socioeconomic background? (c) Given that South Korea has the largest gender wage gap among the OECD countries and hence the experiences of male and female graduates in the labour market are quite different, how does the impact of socioeconomic background on graduates' earnings vary by gender?

Whilst this paper asks important questions regarding the role of higher education in levelling the earnings playing field and will therefore provide valuable information for policymakers and students, as with any analysis, there are caveats. First, we focus solely on wages as the outcome of higher education, ignoring both non-pecuniary benefits to the individual, such as job satisfaction, and social benefits. Second, though the KEEP data allow us to control for a large set of observable characteristics, there may still be selection bias in our estimates caused by unobservable differences among individuals that determine earnings and that may be correlated with socioeconomic background. From this perspective, our estimates should not be interpreted as causal.

\section{The South Korean higher education system}

Since the focus of this paper is on graduate earnings, a brief description of the South Korean higher education system is merited. Higher education is provided primarily by 2-year and 4-year colleges, with 2-year colleges providing more vocational programmes with a technical specialisation. As a result, 2-year colleges are considered as a direct route to employment in South Korea, rather than necessarily a steppingstone towards a 4-year college programme. By contrast, 4-year colleges provide a more general academic curriculum. South Korea now has almost universal 
secondary school enrolment; approximately $99.7 \%$ of students attend. After graduating from upper secondary schools, students can choose whether or not to attend a college, and if choosing to attend, they can select either 4-year academic colleges or 2-year polytechnic colleges depending on their career goals and indeed their scores on a College Scholastic Ability Test $\left(\mathrm{CSAT}^{1}\right)$. On average, 4-year colleges are more academically selective.

In 2019, 430 colleges and universities offered either a 4-year bachelor's degree or a 2-year associate degree. Specifically, there were 191 4-year colleges, 137 2-year colleges, and 102 other types of college generally offering 2-year options. In 2019, 67.8\% of high school graduates enrolled in a degree of some kind. Among students enrolled in tertiary institutions, 66 and $21 \%$ of students enrolled in 4-year and 2-year colleges, respectively (Korean Ministry of Education, 2019). The college enrolment rate in South Korea is high by international standards. For example, in the UK, approximately $50 \%$ of the cohort enrol in tertiary education, and in the USA, around 40\% enrol (NCES, 2019; UK Department for Education, 2019). Participation in tertiary education in South Korea is arguably therefore almost saturated, especially among individuals from socioeconomically advantaged families (Byun \& Park, 2017).

Although South Korea has mass higher education, entry is still competitive and on the basis of a national assessment, CSAT. Many students who are not satisfied with their scores on CSAT, held once a year, tend to retake the test and enter college in a later year. In 2018, approximately $20 \%$ of students enrolled in colleges had retaken the CSAT at least once (KESS, 2019). Retakes are counter-intuitively related to socioeconomic background. Richer students can afford to do more retakes (and hence have a better chance of achieving the score needed to enter a more prestigious institution) due to the high cost of college admission preparation, particularly private tutoring. For instance, in some high schools in the wealthiest neighbourhoods in Seoul, more than half of high school students retake the exam and enter college in the following years, seeking to attend a more prestigious institution (Jung et al., 2019).

Overall, a late entry into the labour market is a feature of the South Korean system. In addition to the trend of CSAT retakes, all males aged between 18 and 30 in South Korea are required to do military service for approximately 2 years. According to the Ministry of the National Defence, about $85 \%$ of males do this between the ages of 20 and 22 . Also, many college students take a semester or year off to prepare for English language examinations and various other qualifications. As a result, it takes approximately 12.3 semesters (two semesters per year) to graduate from college in South Korea (14.3 semesters for males and 9.9 semesters for females (Yi, 2016)). Given this, any analysis of graduates' labour market outcomes needs to focus on individuals' earnings at a somewhat older age, namely when individuals have had a chance to have some time in the labour market, normally in their mid-30s.

\footnotetext{
${ }^{1}$ The College Scholastic Ability Test (CSAT) is designed to measure students' achievement in the National Curriculum standards and scholastic aptitude for higher education. It aims to assess higher order thinking skills in the six study areas: Language Arts, Mathematics, English, Korean History, Investigation, and Second Foreign Languages. Every November, around 600,000 Korean students sit the CSAT, consisting of 8-hour examinations (KICE, 2019).
} 


\section{Existing literature}

\section{The return to higher education in South Korea}

In South Korea, the wage premium associated with more years of schooling and higher levels of educational attainment has decreased as participation in secondary and higher education has substantially increased (Joo, 2018; Lee, 2011). Although the evidence suggests that there remains a wage premium from a degree in South Korea, there is also increasing heterogeneity in graduates' earnings. Yi and Kim (2016), for instance, found that 2-year and 4-year college graduates earn 5.3 and $14.8 \%$ more, respectively, than high school graduates when controlling for work-related characteristics, namely workplace size, firm type, and location. The evidence is mixed, however. Some studies have even suggested that the wage premium from a degree is, in some circumstances, zero in South Korea (e.g., Joo, 2018).

There is also now a sizeable literature exploring the relationship between college prestige and the heterogeneity in graduates' earnings in South Korea (Han et al., 2012; Lee et al., 2018). This literature indicates that the prestige of the 4-year institution that a graduate attended has a strong positive effect on his/her initial job stability and current income (Jung $\&$ Lee, 2016). The premium for graduates from Seoul National University, for example, one of the most prestigious institutions in South Korea, is estimated to be around $12 \%$ over the earnings of graduates from other less selective 4-year institutions (Han et al., 2012). The literature also suggests bigger quality differences, as measured by various indicators, e.g., reputation, learning environments, and students' outcomes, within the group of 4-year colleges compared to 2-year colleges (e.g., Lee, 2011; Lee et al., 2014; Park, 2014; Yi \& Kim, 2016). Generally, the evidence from the existing literature shows that the mean gap in earnings between graduates from 2-year and 4-year colleges may have shrunk or even become zero for graduates from many institutions, bar those from a few top 4-year institutions (Park, 2014). The shrinking earning gap between 2-year and 4-year college graduates is consistent with the greater heterogeneity in 4-year college graduates' earnings (Oh \& Chae, 2014). Explaining the sources of such heterogeneity in graduate earnings is important, and one potential explanation is the family background of graduates, an issue we explore in this paper.

\section{The heterogeneity in returns to higher education by gender}

South Korean labour market data also suggests a high heterogeneity in returns to higher education by gender. In 2019, South Korea had the largest gender wage gap, at $32.5 \%$ among the OECD countries (the OECD average was 12.9\% (OECD, 2021)). Traditional Korean society has sharply defined gender roles, and as a result, females, even those with a college degree, have long experienced various forms of discrimination in the labour market. The empirical evidence suggests women experience occupational and industrial segregation, lower earnings than males doing similar jobs, and fewer promotion opportunities (Kim \& Voos, 2007). The situation is not static, however. Though the gap is still large by international standards, the gender wage gap has gradually decreased since the Equal Employment Opportunity Act enacted in 1988. This Act enabled workers to be legally protected against discrimination on the basis of marital status and pregnancy (Hong, 2011; Monk-Turner \& Turner, 2004). For instance, females, on average, earned $68 \%$ of male earnings in 2019 , which is an improvement on the 1980 s when women earned just $40 \%$ of male earnings. 
One of the significant factors determining the large pay gap between the genders is female career interruption or challenges when returning to work for females after pregnancy and undertaking childcare (Shin, 2011; Kim, 2017). Evidence on the gender wage gap for younger people, i.e., relatively new entrants to the labour market, is therefore mixed. Some studies, for instance, have shown that there is no significant disparity in the earnings and employment rates of males and females for recent graduates in their late 20s, who have not yet experienced any career interruption (Kim, 2017; Kwon, 2018). This is consistent with various statistics that confirm that males and females have similar earnings in their mid-20s right after college graduation but that the gap widens between the genders in older workers, particularly after the age of 30 (Statistics Korea, 2018). Simultaneously, however, much literature has also suggested that more than $80 \%$ of females in their 20 s have reported experiencing gender inequality in the labour market, and some recent studies have even suggested that taking other characteristics into account, female graduates, on average, earn less than their male counterparts (Choi et al., 2016; Kim \& Oh, 2019). Female graduates from more selective 4-year institutions also appear to face even greater earning inequalities in the labour market than those from less-selective 4-year or 2-year colleges (Kim \& Oh, 2019). Given the mixed evidence on the extent of the gender wage gap, particularly for young graduates, we model the determinants of earnings separately for males and females.

\section{Socioeconomic gaps in graduates' earnings}

This study will contribute to the significant literature from a range of contexts that has suggested a major impact from the family background on graduates' earnings, even after allowing for differences in the higher education institution they attended and the degree subject they studied. Evidence on this issue for the South Korean context will be provided, using a similar methodology to that used in the existing literature (e.g., Britton et al., 2019; Chetty et al., 2017).

Whilst there is considerable evidence of heterogeneity in returns to higher education by subject and institution, there is very little evidence on how graduates' earnings vary by socioeconomic background (Crawford \& Erve, 2015). Further, the existing literature suggests contrasting results in different contexts, which is why empirical evidence from an Asian context is so important. In the USA, for example, there is a body of literature that has found significant differences in the return to education by family background, as measured by parental education level and occupational status (e.g., Altonji \& Dunn, 1996; Ashenfelter \& Rouse, 1997). More recently and using larger-scale administrative data, Chetty et al. (2017) found that graduates from low-income and high-income families had very similar labour market outcomes after allowing for higher education institution attended. The result suggests that family background may not be a strong predictor of graduates' labour market outcomes, once we allow for the specific college attended, and that in the USA, colleges do play a pivotal role in levelling the earnings playing field for students from different socioeconomic backgrounds.

In the UK, by contrast, much of the literature has continued to find significant differences between the earnings of graduates from the lower and higher socioeconomic backgrounds, even after allowing for a rich array of characteristics, namely higher education institution attended and subject discipline (e.g., Britton et al., 2019; Crawford \& Erve, 2015). For instance, graduates whose parents were working in a top NS-SEC occupation are more likely themselves to end up working in one of these top jobs and to earn more than graduates whose 
parents worked in routine occupations (Crawford \& Vignoles, 2014; Macmillan et al., 2013). This applies even when comparing graduates who attended the same university. Parental income level also remains a strong predictor of children's subsequent graduate income level in the UK, although the impact of family income on graduates' earnings is halved after allowing for institution attended and subject taken (Britton et al., 2019). This body of literature implies that universities in the UK do not appear to fully level the playing field and eliminate the socioeconomic gap in earnings.

In South Korea, there are many studies showing a strong positive relationship between father's and children's income levels (An \& Jeon, 2008; Choi \& Min, 2015; Jang, 1999; Yeo, 2008). For example, Choi and Min (2015) found that a son's earnings are, on average, $19 \%$ higher if he comes from the top fifth of households in terms of income, as compared to coming from the bottom quintile. There is also evidence suggesting that the likelihood of becoming a graduate and the quality of higher education institution attended is related to family background. Yeo (2008) provided empirical evidence that students from richer families are more likely to attend better quality colleges and as a result tend to have higher wages than graduates from poorer families. To the best of our knowledge however, there are no studies from South Korea that have estimated the extent of the socioeconomic gap in earnings for graduates, after allowing for differences in the quality of university attended and subject studied. This paper seeks to fill this gap.

\section{Methodology}

\section{Data}

The data used here are from the Korean Education and Employment Panel (KEEP) survey. The KEEP, first established in 2004, is a longitudinal survey of Korean individuals as well as households. The dataset was designed to examine the relationship between a respondent's household socioeconomic status, their educational achievement, and subsequent labour market outcomes. In its first year, a total of 6000 individuals were selected as a target sample, comprising 2000 middle school seniors and 4000 high school seniors. The selected individuals were then followed up until 2015, with 12 waves of yearly surveys. The sample for the KEEP dataset is stratified into 15 regions (Seoul, six metropolitan cities, and eight provinces), and 4175 middle and high schools across the country were selected through the stratified and multistage sampling methods. Stratification was applied at the school, class, and student level (KRIVET, 2021). Hence, the KEEP was designed to provide a nationally representative sample of Korean middle and high school students. The KEEP is well suited to address our research questions, given that, in comparison to other nationally representative datasets, it includes a richer array of information on Korean youths' educational and labour market experiences, including their high school academic achievement. It also provides information on family background, namely parental income and assets, which is central to our focus.

\section{Sample}

In this particular study, the sample was restricted to those who graduated from high school in 2005, who had achieved an undergraduate degree or higher, and who earn at least the minimum legal wage in South Korea as of 2015. Hence, the usable sample is 1229 individuals 
who attended either 2-year or 4-year colleges and provided usable salary information. This study focuses on the respondents who entered higher education between 2005 and 2009 to allow for the widespread late entry into universities discussed above. In 2015, the targeted individuals were age 28 or 29 , and it might be argued that this stage of life is still relatively early to assess the career path of individuals in the South Korean context. With this slight caveat, the data are nonetheless particularly rich in terms of trying to understand the factors that explain wage differences between graduates. Specifically, the data include sufficient information on students' subject of degree and higher education institution, as well as their socioeconomic background and prior academic achievement.

\section{Main variables}

\section{Wages}

Individuals' job-related data were collected from the $12^{\text {th }}$ wave of the KEEP survey in 2015. The KEEP survey does not record each individual's income but instead provides (a) the combined income of an individual and his/her spouse and (b) the spouse's income. Therefore, the spouse's income was subtracted from the combined income to obtain the individual's own income. The data have some other limitations. Specifically, data on years of work experience were not collected. To address the issue, we controlled for the year of graduation since individuals who graduated in the same year will, on average, have a similar length of work experience. Whilst this is not an ideal measure of work experience, it will go some way to control for differences in wages associated with differences in work experience.

The natural log of the individual's monthly wage was used as a measure of their income, and the top $0.5 \%$ of observations were excluded as outliers. In addition, individuals earning less than the monthly minimum wage of $1,170,000 \mathrm{KRW}$ (equivalent to £760) in 2015 were considered to be either part-time workers or unemployed, and both were excluded from the sample. We excluded part-time workers because the data were not sufficiently rich to incorporate the reasons why individuals had a part-time job in their late $20 \mathrm{~s}$ and the extent to which it was a choice, related to family, or other nonwork-related issues. Further, we lacked data on hours of work. Our estimates, therefore, focus on the earning differences among graduates in full-time employment. We acknowledge that this means we are missing the impact of characteristics on the employment decision (including the decision to work parttime), but in the absence of a credible instrumental variable to predict employment, we simply acknowledge that we are providing a partial picture which is focused on full-time employees only. As a robustness check, Tables 8 and 9 of Appendix 3 show the characteristics of those excluded from our analysis due to this data restriction, and there is no obvious systematic relationship between employment status and the other explanatory variables that we used in the model.

\section{Family background}

Given the rapid expansion of education opportunities in South Korea, some common timeinvariant proxies for socioeconomic background, e.g., parental education, maybe arguably be less appropriate. In the space of one or two generations, South Korea has gone from having a high level of uneducated workers to a mass higher education society. Hence, parental education is arguably a weaker family background indicator than measures of family income 
and wealth, recognising that the former in particular may vary over time. We therefore build on a large body of existing literature that has attempted to analyse the impact of family income on the earnings of graduates in various contexts (e.g., Britton et al., 2019; Chetty et al., 2017; Kim, 2014). Hence, monthly family income and family assets are both used as proxies for individuals' family backgrounds in our analysis. Another limitation of our data is that to maximise the quality of our two measures of family background, we have had to take them from subsequent years. To the extent that family income changes over time, this may be an issue, though we expect a high correlation between family incomes over time. The family income data were collected from the $1^{\text {st }}$ wave of the KEEP in 2004, whereas the family asset data used were collected in the $2^{\text {nd }}$ wave in 2005 because the latter was measured as a continuous variable in that sweep. The continuous family asset data from the $2^{\text {nd }}$ wave do, however, have approximately $35 \%$ missing values (see Table 5 of Appendix 1). Therefore, we supplement the wave 2 data with categorical family asset data from the $1^{\text {st }}$ wave, imputing the missing values for the $2^{\text {nd }}$ wave (see Table 6 and 7 of Appendix 2). Given these limitations of our measures of family background, we were careful to test the robustness of our findings by using the two alternative measures, namely monthly family income and family assets. In any case, there is evidence that big family investments like tuition fees for higher education are not paid for out of income and hence assets might be a more appropriate indicator of family background in this context (Nam \& Huang, 2009; Zhan \& Sherraden, 2003). The distributions of monthly family income/family assets and their relationship with other indicators of family background, such as the paternal education level and individuals' earnings, are shown in and Figs. 2 and 3 and Tables 10 and 11 of Appendix 4.

\section{College type}

Information about individuals' higher education, such as a college type, institution attended, and the subject of degree, was generally taken from data collected in the year they started their higher education. However, data on each individual's final degree was also used to reflect any change of college or subject during the course of his/her studies. It is also possible for individuals attending 2-year colleges to obtain a bachelor's degree equivalent to a 4-year college graduate if they take an additional year of intensive courses. We have opted to classify such individuals as 2-year college graduates, given some evidence that firms do not treat the additional year as equivalent to a 4-year college degree (KCCE, 2019). Individuals who graduated from foreign universities, open universities, and on-line universities, which accounted for less than $1 \%$ of the sample, were excluded.

\section{Other controls}

Individual's wages are partly determined by their 'ability', broadly defined. Further, the likelihood that an individual enrols in a 4-year or 2-year college is also likely to be determined by his/her ability, in this case his/her academic ability. Hence, it may be that the apparent wage premium for a particular type of college degree may actually be attributable to ability bias, whereby individuals with higher levels of ability select into particular types of college. In our data, we have a measure of earlier academic achievement, prior to entry into higher education, that we can include in our model as a proxy for ability. We are not claiming that this proxy fully measures an individual's productive ability. However, it should provide a measure of academic ability prior to entry into college, which should reduce the ability bias on the 
coefficient on college type for instance. Specifically, we include a measure of an individual's percentile rank score within his/her high school which indicates how well he/she performed relative to other students in the same school. A lower percentile rank indicates better academic achievement.

We also control in our models for whether the college was attended was located in Seoul. This is partly because institutions in the capital city have historically been viewed as higher prestige. However, we also include it because this variable may also proxy the graduate's current location, given the tendency of graduates to remain where they studied, and salaries in Seoul exceed those in other parts of South Korea.

\section{Analytical model}

We estimate the following models on a sample of individuals with earnings at or above the minimum wage in South Korea as of 2015. As discussed above, we use two different measures of family background, e.g., family income and assets, which are measured in different years. Despite a year gap between the two measures, we argue this is not a major issue due to the permanent nature of family assets. To estimate the effects of monthly family income and family assets separately on individuals' earnings conditional on various educational characteristics, we use the following models:

$$
\begin{aligned}
& y_{i_{2015}}=\alpha+\beta_{1} P_{1_{2004}}+\chi X_{i}+\mu_{i} \\
& y_{i_{2015}}=\alpha+\beta_{1} P_{2_{2005}}+\chi X_{i}+\mu_{i}
\end{aligned}
$$

where $y_{i_{2015}}$ is log monthly earnings of individual $i$ in 2015 when individuals were age 28/29, $P_{1_{2004}}$ is monthly family income in $2004, P_{2_{2005}}$ is a measure of family assets in 2005, $X_{i}$ is a vector of control variables, and $\mu_{i}$ is a normally distributed error term capturing unobserved random factors that influence earnings. The main parameter of interest is $\beta_{1}$, which measures the relationship between monthly family income/family assets and wages. The results from models that only include family background will be presented first. This provides an indication of the raw correlation between family background and individuals' wages at age 28/29. Additional controls, such as the year of graduation, previous academic achievement, higher education institution attended, and degree subject, are then sequentially added to the model. The change in $\beta_{1}$ indicates the extent to which the various control variables mediate or exacerbate the relationship between family background and individuals' wages.

There may of course be interaction effects between family background and different types of higher education institutions. To determine whether this is the case, we also estimate the following models:

$$
\begin{aligned}
& y_{i_{2015}}=\alpha+\beta_{1} P_{1_{2004}}+\beta_{2}\left(P_{1_{2004}} \cdot Q_{i}\right)+\chi X_{i}+\mu_{i} \\
& y_{i_{2015}}=\alpha+\beta_{1} P_{2_{2005}}+\beta_{2}\left(P_{2_{2005}} \cdot Q_{i}\right)+\chi X_{i}+\mu_{i}
\end{aligned}
$$

where $Q_{i}$ is a $0 / 1$ dummy variable indicating whether the individual ever enrolled in a 2year (value 0 ) or 4-year college (value 1) and both $P_{1_{2004}} \cdot Q_{i}$ and $P_{2_{2005}} \cdot Q_{i}$ are interaction 
terms between monthly family income/family assets and college type. The variable measuring college type records whether the individual ever enrolled in a particular college type over the period 2005-2009, capturing 'late' enrolment into college. The main parameters of interest here are $\beta_{1}$ and $\beta_{2}$, which capture the combined effect of family background and the interaction effect between family background and college type, on the outcome variable, namely wages.

\section{Estimation and results}

\section{The socioeconomic gap in the earnings of graduates}

Table 1 shows the results of two separate regression models of the log wages of graduates on either the log of monthly family income (equation 1) or the log of family assets (equation 2). Both family background variables are significantly associated with graduates' income, consistent with the existing literature (Choi \& Min, 2015; Nam, 2008). When monthly family income and family assets increase by $1 \%$ graduates' wages, on average, these increase by $6.5 \%$ and $2.9 \%$, respectively. Clearly, graduates' earnings are correlated with their family background, as has been found in almost all countries.

The focus of this paper is on the role of different types of a college degree in explaining this positive correlation between family background and graduates' earnings, and we include various measures of the individual's college experience in the model. As discussed earlier, all subsequent models are estimated separately by gender. The tables below show the relationship between family background (as measured by monthly family income in Table 2 and family assets in Table 3) and earnings, conditional on the individual's academic achievement within his/her high school, type of college degree (2- or 4-year), whether the college was located in Seoul, the year of graduation, and the discipline of their degree.

Columns (1) and (4) in Table 2 show the raw correlation between monthly family income and graduates' wages by gender. Monthly family income is positively correlated with the graduate's income for both males and females, but the relationship is statistically significant only for females. Additional controls reduce the correlation between family income and graduate earnings to almost zero for males. For females, by contrast, there remains a positive and statistically significant relationship between family income and graduate earnings after allowing for high school achievement, college type, location, graduation year, and the subject of study.

Similar to the models in Table 2 for monthly family income, columns (1) and (4) in Table 3 indicate the raw correlation between family assets and graduates' wages by gender. With the sample split by gender, sample sizes are reduced, and the correlation between family assets and

Table 1 Family background and earnings

\begin{tabular}{llllll}
\hline & & Coef. (Std. Err.) & $t$ & $p>|t|$ & Obs. \\
\hline (1) & Monthly family income & $0.065^{*}(0.035)$ & 1.80 & 0.072 & 760 \\
$(2)$ & Family assets & $0.029^{*}(0.016)$ & 1.71 & 0.087 & 777 \\
\hline
\end{tabular}

Note: this table presents estimates from simple OLS regressions of graduate's wages on family backgrounds only (no control variables were added), as measured by (1) monthly family income and (2) family assets. Each cell reports the coefficients on family assets and monthly family income from a separate regression, with standard errors in parenthesis $(* p<0.10, * * p<0.05$, and $* * * p<0.01)$ 
Table 2 The conditional relationships between monthly family income and wage by gender

\begin{tabular}{|c|c|c|c|c|c|c|}
\hline & \multicolumn{3}{|l|}{ Male } & \multicolumn{3}{|l|}{ Female } \\
\hline & (1) & (2) & (3) & (4) & (5) & (6) \\
\hline $\begin{array}{l}\text { Monthly family } \\
\text { income }\end{array}$ & $\begin{array}{l}0.033 \\
\quad(0.051)\end{array}$ & $\begin{array}{l}0.009 \\
\quad(0.053)\end{array}$ & $\begin{array}{l}0.006 \\
(0.054)\end{array}$ & $\begin{array}{l}0.095^{*} \\
(0.053)\end{array}$ & $\begin{array}{l}0.097 * \\
(0.056)\end{array}$ & $\begin{array}{l}0.093 * \\
(0.056)\end{array}$ \\
\hline $\begin{array}{l}\text { HS academic } \\
\text { achievement }\end{array}$ & No & $\begin{array}{r}-0.001 \\
(0.001)\end{array}$ & $\begin{array}{l}-0.001 \\
\quad(0.001)\end{array}$ & No & $\begin{aligned}-0.001 \\
(0.001)\end{aligned}$ & $\begin{array}{r}-0.000 \\
(0.001)\end{array}$ \\
\hline $\begin{array}{l}\text { College type } \\
\qquad(0=2 \text { years; } 1=4 \\
\text { years })\end{array}$ & No & $\begin{array}{l}0.104 \\
\quad(0.082)\end{array}$ & $\begin{array}{l}0.096 \\
\quad(0.084)\end{array}$ & No & $\begin{array}{r}-0.050 \\
\quad(0.091)\end{array}$ & $\begin{array}{r}-0.041 \\
\quad(0.095)\end{array}$ \\
\hline In-Seoul dummy & No & $\begin{array}{l}0.126 \\
(0.088)\end{array}$ & $\begin{array}{l}0.126 \\
\quad(0.088)\end{array}$ & No & $\begin{array}{l}0.033 \\
\quad(0.082)\end{array}$ & $\begin{array}{l}0.022 \\
\quad(0.083)\end{array}$ \\
\hline Graduation year & No & Yes & Yes & No & Yes & Yes \\
\hline $\begin{array}{l}\text { Discipline of } \\
\text { degree }\end{array}$ & No & No & Yes & No & No & Yes \\
\hline$R^{2}$ & 0.001 & 0.047 & 0.054 & 0.010 & 0.036 & 0.053 \\
\hline$N$ & 405 & 405 & 405 & 355 & 355 & 355 \\
\hline
\end{tabular}

Note: this table presents estimates from OLS regressions of graduate's wage on various control variables including a family background as measured by monthly family income. Each cell reports the coefficient on various control variables from a separate regression, with standard errors in parenthesis $\left({ }^{*} p<0.10, * * p<0.05\right.$, and $\left.* * * p<0.01\right)$. Coefficients for each discipline subject and graduation year are omitted. A total number of samples is 760 (see row (1) in Table 1)

graduates' wages for males is statistically insignificant. For females, the magnitude of the coefficients suggests a stronger but statistically insignificant relationship between family assets and graduates' wages.

Allowing for college type, whether the college was located in Seoul, high school academic achievement, and the year of graduation in columns (2) and (5) reduces the correlation between family assets and male wages from 1.5 to $0.1 \%$, and the coefficient remains

Table 3 The conditional relationships between family assets and wages by gender

\begin{tabular}{|c|c|c|c|c|c|c|}
\hline & \multicolumn{3}{|l|}{ Male } & \multicolumn{3}{|l|}{ Female } \\
\hline & (1) & (2) & (3) & (4) & (5) & (6) \\
\hline Family assets & $\begin{array}{l}0.015 \\
\quad(0.024)\end{array}$ & $\begin{array}{l}0.001 \\
\quad(0.026)\end{array}$ & $\begin{array}{l}-0.001 \\
\quad(0.026)\end{array}$ & $\begin{array}{l}0.034 \\
\quad(0.023)\end{array}$ & $\begin{array}{l}0.030 \\
\quad(0.023)\end{array}$ & $\begin{array}{l}0.029 \\
\quad(0.024)\end{array}$ \\
\hline $\begin{array}{l}\text { HS academic } \\
\text { achievement }\end{array}$ & No & $\begin{array}{l}-0.001 \\
\quad(0.001)\end{array}$ & $\begin{array}{l}-0.001 \\
\quad(0.001)\end{array}$ & No & $\begin{array}{l}-0.000 \\
\quad(0.001)\end{array}$ & $\begin{array}{l}-0.000 \\
\quad(0.001)\end{array}$ \\
\hline $\begin{array}{l}\text { College type } \\
(0=2 \text { years; } 1=4 \\
\text { years })\end{array}$ & No & $\begin{array}{l}0.178 * * \\
\quad(0.082)\end{array}$ & $\begin{array}{l}0.174 * * \\
\quad(0.084)\end{array}$ & No & $\begin{array}{l}-0.042 \\
\quad(0.090)\end{array}$ & $\begin{array}{r}-0.037 \\
\quad(0.094)\end{array}$ \\
\hline In-Seoul dummy & No & $0.098(0.089)$ & $0.098(0.090)$ & No & $\begin{array}{l}0.046 \\
\quad(0.080)\end{array}$ & $\begin{array}{l}0.033 \\
\quad(0.081)\end{array}$ \\
\hline Graduation year & No & Yes & Yes & No & Yes & Yes \\
\hline Discipline of degree & No & No & Yes & No & No & Yes \\
\hline$R^{2}$ & 0.001 & 0.055 & 0.059 & 0.007 & 0.031 & 0.046 \\
\hline$N$ & 416 & 416 & 416 & 361 & 361 & 361 \\
\hline
\end{tabular}

Note: this table presents estimates from OLS regressions of graduate's wage on various control variables including a family background as measured by family assets. Each cell reports the coefficient on various control variables from a separate regression, with standard errors in parenthesis $\left({ }^{*} p<0.10,{ }^{*} p<0.05\right.$, and $\left.* * * p<0.01\right)$. Coefficients for each discipline subject and graduation year are omitted. A total number of samples is 777 (see row (2) in Table 1) 
statistically insignificant. The impact of college type on male wages becomes statistically significant, whilst the impact of family assets decreases, and male graduates who attended a 4year college, on average, earn approximately $17 \%$ more than those who attended a 2-year college. For females, the coefficient on family assets slightly decreases from 3.4 to $3.0 \%$ after controlling for prior academic achievement, institution attended, whether the college was located in Seoul, and the year of graduation. Allowing for the subject of a degree in columns (3) and (6) does not significantly impact the coefficient on family assets for either gender.

For females, the coefficients on monthly family income (Table 2) and family assets (Table 3) do not significantly decrease when adding more control variables describing the individual's education. This is not a common finding in the literature on social mobility from other countries. Normally, a strong relationship between family background and graduate earnings tends to be mediated by the inclusion of variables capturing different aspects of the graduate's higher education. This is because a more advantaged family background enables individuals to have higher levels of academic achievement and hence affords access to a more prestigious and higher-earning degree. This is one route by which family background impacts graduates' earnings. Here, by contrast, the results are consistent with females from higher socioeconomic backgrounds being more likely to earn higher wages than those from lower family background, regardless of college attended and degree subject studied. The results suggest that for female graduates, monthly family income (and perhaps the associated social capital and networks) is more important than college and degree subject in determining their labour market opportunities and earnings.

Overall, the results reveal that family income and assets are not strong predictors of graduates' wages, at least for male graduates. In this sense, college in South Korea levels the playing field in terms of male wages. That is, the correlation between family background and male wages is essentially zero after allowing for institution attended and the subject of degree. For females, on the other hand, college does not entirely level the playing field in terms of wages. Monthly family income remains a strong predictor of female graduate wages, even after controlling for college attended and degree subject. As we noted earlier, we are mindful that our estimates are correlational and do not necessarily show a causal relationship between family background and graduate earnings.

\section{The interaction effect between family background and college type}

We have a conditional hypothesis, in which the relationship between college type and graduates' earnings depends on the level of family income or assets, for example, because higher income households may be in a position to provide additional support that is complementary to a 4-year college degree and hence increase the return for these students. To put it differently, the wage premium for 2-year and 4-year colleges may also vary by graduates' family background. We therefore also explored whether there was any interaction effect between family background and college type. Four different models (Table 4) were estimated with interaction terms between the two different family background variables and college type, separately by gender.

In column (3) of Table 4, the interaction term between family assets and college type shows a statistically significant correlation with male wages. A mean negative relationship between family assets and male wages, and indeed college type and male wages, is offset by a positive significant interaction between family assets and college type $(p<0.10)$. The results weakly suggest that, on average, attending a 4-year college is negatively associated with wages for males. However, those with greater levels of family assets earn a higher return from attending a 4-year college. This implies 
Table 4 Interaction effects between family backgrounds and college type

\begin{tabular}{|c|c|c|c|c|c|}
\hline & \multicolumn{2}{|c|}{$\begin{array}{l}\text { Monthly family income } \\
\text { and college type }\end{array}$} & & \multicolumn{2}{|c|}{$\begin{array}{l}\text { Family assets and } \\
\text { college type }\end{array}$} \\
\hline & $\begin{array}{l}\text { Male } \\
(1)\end{array}$ & $\begin{array}{l}\text { Female } \\
(2)\end{array}$ & & $\begin{array}{l}\text { Male } \\
(3)\end{array}$ & $\begin{array}{l}\text { Female } \\
\text { (4) }\end{array}$ \\
\hline Monthly family income & $\begin{array}{r}-0.015 \\
\quad(0.086)\end{array}$ & $\begin{array}{l}0.116 \\
\quad(0.081)\end{array}$ & Family assets & $\begin{array}{r}-0.057 \\
(0.039)\end{array}$ & $\begin{array}{l}0.062 * \\
\quad(0.034)\end{array}$ \\
\hline $\begin{array}{l}\text { College type }(0=2 \text { years; } \\
\quad 1=4 \text { years })\end{array}$ & $\begin{array}{r}-0.091 \\
\quad(0.601)\end{array}$ & $\begin{array}{l}0.191 \\
\quad(0.611)\end{array}$ & $\begin{array}{l}\text { College type } \\
\quad(2 \text { years }=0 ; 4 \text { years }=1)\end{array}$ & $\begin{array}{r}-0.748 \\
\quad(0.480)\end{array}$ & $\begin{array}{l}0.518 \\
\quad(0.427)\end{array}$ \\
\hline $\begin{array}{l}\text { Interaction term } \\
\quad \text { (mfincome\#coltype) }\end{array}$ & $\begin{array}{l}0.034 \\
\quad(0.110)\end{array}$ & $\begin{array}{l}-0.043 \\
\quad(0.112)\end{array}$ & $\begin{array}{l}\text { Interaction term } \\
\quad(\text { assets \# } \# \text { coltype })\end{array}$ & $\begin{array}{l}0.103 * \\
(0.053)\end{array}$ & $\begin{aligned}-0.063 \\
\quad(0.047)\end{aligned}$ \\
\hline $\begin{array}{l}\text { In-Seoul dummy } \\
\quad(0=\text { outside; } 1=\text { Seoul })\end{array}$ & $\begin{array}{l}0.122 \\
\quad(0.089)\end{array}$ & $\begin{array}{l}0.028 \\
\quad(0.085)\end{array}$ & $\begin{array}{l}\text { In-Seoul dummy } \\
\quad(0=\text { outside; } 1=\text { Seoul })\end{array}$ & $\begin{array}{l}0.071 \\
\quad(0.090)\end{array}$ & $\begin{array}{l}0.053 \\
\quad(0.082)\end{array}$ \\
\hline HS academic achievement & $\begin{aligned}-0.001 \\
\quad(0.001)\end{aligned}$ & $\begin{aligned}-0.000 \\
(0.001)\end{aligned}$ & $\begin{array}{l}\text { HS academic } \\
\text { achievement }\end{array}$ & $\begin{array}{l}-0.001 \\
(0.001)\end{array}$ & $\begin{aligned}-0.000 \\
(0.001)\end{aligned}$ \\
\hline Discipline category & Yes & Yes & Discipline category & Yes & Yes \\
\hline Graduation year & Yes & Yes & Graduation year & Yes & Yes \\
\hline$R^{2}$ & 0.055 & 0.054 & $R^{2}$ & 0.068 & 0.052 \\
\hline$N$ & 405 & 355 & $N$ & 416 & 361 \\
\hline
\end{tabular}

Note: this table presents estimates from OLS regressions of graduate's wage on various control variables with the interaction terms between family backgrounds and college type. Each cell reports the coefficient on various control variables from a separate regression, with standard errors in parenthesis $(* p<0.10, * * p<0.05$, and $* * * p<0.01)$. Coefficients for each discipline subject and graduation year are omitted

that though there is no overall effect of family assets on earnings, there indeed exists a crossover interaction, implying the effect of college type on graduates' earnings varies, depending on the level of family assets. In other words, male graduates with greater family assets, on average, have higher wages when attending a 4-year college, whereas male graduates with lower family assets, on average, earn more when attending a 2-year college. Figure 1 shows how male graduates' income level changes depending on both family assets and different college types.

Some caution is required however, in interpreting the above result since for males, the relationship between family income and wages is statistically insignificant, as are college type and the interaction between college type and family income. This clearly begs the question as to

$$
\text { 2-year } \mathbf{n} \text { 4-year }
$$

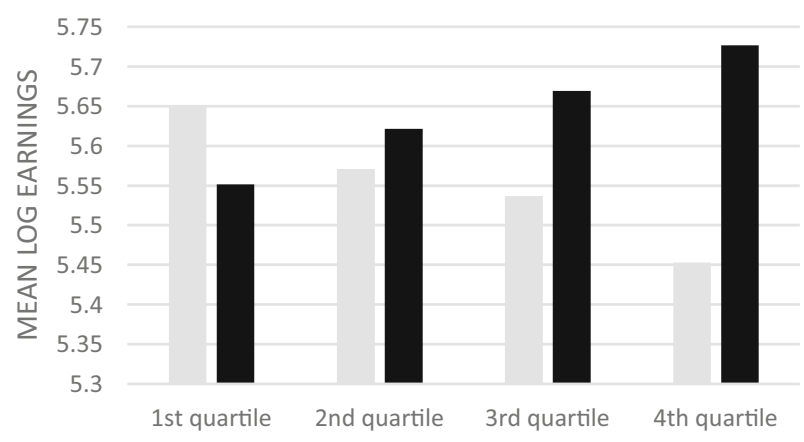

FAMILY ASSETS

Fig. 1 Predicted wage for male graduates at the $1^{\text {st }}$ (bottom), $2^{\text {nd }}, 3^{\text {rd }}$, and $4^{\text {th }}$ (top) quartiles of the family asset distribution, by college type. The corresponding table is Table 4, column (3) 
why family assets interact significantly with college type but family income is insignificant when interacted with college type. Family income and assets are of course distinct measures, and it is likely that family assets are more important for education investment decisions. A plausible interpretation may relate to the cost of private tutoring. South Korea is famous for the emphasis families place on education, and the private sector plays a pivotal role in the investments parents make. For instance, more than $60 \%$ of high school students participate in private tutoring, and it accounted for roughly $15 \%$ of total household expenditure in 2008 (Oh \& Kim, 2011; Statistics Korea, 2011). It should also be noted that private tutoring for CSAT preparation often costs more than three million KRW (equivalent to 2000 ) per month, which is much higher than average monthly household income, which was roughly two million KRW (£1250) in 2010 (Oh, 2013; Statistics Korea, 2011). As such, family assets are likely to be key in bridging the gap between family income and the costs of private tutoring. Given that a body of literature has found that private tutoring is, on average, positively associated with students' academic performance, it may be that family assets, rather than income, better predict students' academic performance and in turn their labour market outcomes. For females, the interaction terms are statistically insignificant. It appears that the value of a 2-year or 4-year degree does not vary by family background for females. The results confirm the findings from the previous tables, namely that for females, higher levels of family income/assets are associated with higher earnings irrespective of college attended or subject studied.

\section{Discussion and conclusion}

This paper contributes to the existing literature by providing an estimate of the magnitude of the socioeconomic gap in graduates' earnings in a non-Western context, namely South Korea. In South Korea, much research and policy attention has been paid to the socioeconomic gap in participation at university and indeed to the intergenerational correlation in income. Far less attention has been paid however, to whether a college degree can level the playing field in labour market terms, such that family background is no longer correlated with graduates' earnings. This paper provides new empirical evidence on this issue.

We find that family background, measured by either monthly family income or family assets, does not, on average, play a significant role in determining the wages of male graduates, after allowing for institution attended and degree subject. However, our results also suggest that the wage premium for 2-year and 4-year colleges for males does vary by family background. Indeed, males with fewer family assets earn more from a 2-year college degree than from a 4year college degree. Plausible interpretations for this observation include greater quality variation within the 4-year college group and individuals from poorer backgrounds attending, on average, less selective 4-year colleges. In South Korea, since 2000, the number of 4-year colleges has dramatically increased, leading to a large number of less selective institutions, particularly outside of Seoul. As a result, students who would not have been able to attend any type of college in the past are now enrolled in these less selective 4-year colleges. This implies that the heterogeneity in academic achievement levels among 4-year college graduates has also increased, with consequences for their labour market outcomes (Oh \& Chae, 2014). More socioeconomically advantaged males tend to access top 4-year college degrees that attract a higher wage premium. The implication is that whilst 4-year college degrees remain a good option for males from more advantaged backgrounds, contrary to popular belief, they do not always attract a higher wage premium than 2-year college degrees for other students. 
By contrast, family background is still a strong predictor of female graduate wages, even after controlling for institution attended and subject discipline and even in models that include interactions between college type and family background. In other words, a degree does not level the playing field for female graduates, in terms of their earnings. We noted that South Korea also has the largest gender wage gap of the OECD countries. This may be relevant in terms of understanding why higher education does not eliminate socioeconomic gaps in wages for females. For example, for female graduates, it may be that social networks and social capital are more important in securing a good job, given the evidence of potential labour market discrimination against females as measured by the gender wage gap. A more advantaged family background may be necessary to provide female graduates with better social networks and capital that they need to succeed in the labour market.

Clearly, these findings should be considered in light of some of the data limitations we faced. First, the KEEP data does not include high-quality administrative data on individuals' family income and assets. Instead, respondents were asked to recall the information retrospectively. This may result in measurement error that, if classical in nature, will tend to attenuate the coefficients on the family background variables. Second, we were only able to allow for the type of college attended (2-year or 4-year). We were not able to control for individual institution fixed effects due to sample size limitations and confidentiality issues. Hence, our college type categories include a heterogeneous range of institutions that may hide big differences in the earnings of graduates, depending on the prestige of the institution attended. It is possible that the magnitude of the socioeconomic gaps in the earnings of graduates who went to the exact same institution may differ from the estimates that we provide. Future research could usefully focus on (a) the mechanisms by which family background appears to influence the earnings of female graduates to a greater extent and (b) the differences in labour market outcomes (by family background) for different colleges in South Korea. The latter would require access to large-scale administrative data to generate sample sizes sufficient to compare graduates from individual institutions, along the lines of the large-scale data used by Britton et al. (2019) or Chetty et al. (2017).

In conclusion, simply expanding the educational opportunities and improving access to higher education in the past few decades in South Korea has not necessarily narrowed the socioeconomic gap in the earnings of graduates. In terms of male earnings, it appears that a 4year college degree may only offer a wage premium over a 2-year degree for males from a more socioeconomically advantaged background. These issues should be taken into account when implementing future higher education policies and might support a shift in focus from further expansion of higher education to a greater emphasis on quality improvement, which is indeed in line with recent government policy (Hwang, 2018; KHERI, 2020).

\section{Appendix 1}

Table 5

\begin{tabular}{lllll}
\hline Variables & \# missing & \# present & Total & $\%$ missing \\
\hline $1^{\text {st }}$ wave family assets (categorical) & 27 & 1202 & 1229 & 2.20 \\
$2^{\text {nd }}$ wave family assets (continuous) & 426 & 803 & 1229 & 34.66 \\
\hline
\end{tabular}

Note: this table presents the number of missing values for the variable of family assets from the $1^{\text {st }}$ and $2^{\text {nd }}$ waves 


\section{Appendix 2}

Table 6

\begin{tabular}{lllll}
\hline Value & KRW & Obs & \# Obs imputed & $\begin{array}{l}\text { Mid-value of each band } \\
\text { (KRW/unit: } 10,000)\end{array}$ \\
\hline 1 & Less than $10,000,000$ & & 53 & 500 \\
2 & $10,000,000 \sim 25,000,000$ & 65 & 29 & 1750 \\
3 & $25,000,000 \sim 50,000,000$ & 16 & 43 & 3750 \\
4 & $50,000,000 \sim 75,000,000$ & 157 & 52 & 6250 \\
5 & $75,000,000 \sim 100,000,000$ & 172 & 58 & 8750 \\
6 & $100,000,000 \sim 200,000,000$ & 285 & 94 & 15,000 \\
7 & $200,000,000 \sim 300,000,000$ & 135 & 36 & 25,000 \\
8 & $300,000,000 \sim 400,000,000$ & 70 & 20 & 35,000 \\
9 & $400,000,000 \sim 500,000,000$ & 29 & 12 & 45,000 \\
10 & $500,000,000 \sim 1,000,000,000$ & 46 & 18 & 75,000 \\
11 & $1,000,000,000 \sim 2,000,000,000$ & 15 & 7 & 350,000 \\
12 & $2,000,000,000 \sim 5,000,000,000$ & 2 & 0 & 500,000 \\
13 & More than 5,000,000,000 & 0 & 0 & \\
Total & & 1202 & 412 & \\
\hline
\end{tabular}

Note: this table presents the number of observations with valid information on family assets from the $2^{\text {nd }}$ wave, imputed based on the $1^{\text {st }}$ wave data. We used several steps to impute the missing values for the variable of family assets from the $2^{\text {nd }}$ wave. First, family asset data from the $1^{\text {st }}$ and $2^{\text {nd }}$ waves were reviewed and compared. 412 out of 426 missing values for family assets from the $2^{\text {nd }}$ wave have observations from the $1^{\text {st }}$ wave (see Appendix Table 5 for further details). The mid-value of each band from the $1^{\text {st }}$ wave was imputed for the 412 missing values from the $2^{\text {nd }}$ wave. As a result, we established the new family asset variable, having only 14 missing values

Table 7

\begin{tabular}{llllll}
\hline Variable & Obs. & Mean & Std. Dev. & Min & Max \\
\hline Imputed 2 $2^{\text {nd }}$ wave family assets & 1215 & 9.01 & 1.23 & 3.91 & 11.92 \\
\hline
\end{tabular}

Note: this table shows descriptive statistics for the imputed $2^{\text {nd }}$ wave family asset variable, including 1215 observations

\section{Appendix 3}

Table 8

\begin{tabular}{lcr}
\hline Employment status (0=unemployed; 1=employed) & $z$-value & $p>|z|$ \\
\hline College type & -1.47 & 0.140 \\
In-Seoul dummy & 1.31 & 0.191 \\
Family asset & -1.00 & 0.319 \\
HS academic achievement & 0.95 & 0.344 \\
\hline
\end{tabular}

Note: this table presents a dprobit regression of employment status on various explanatory variables including family background as measured by family assets

Table 9

\begin{tabular}{lcr}
\hline Employment status (0=unemployed; 1=employed) & $z$-value & $p>|z|$ \\
\hline College type & -1.49 & 0.137 \\
In-Seoul dummy & 0.66 & 0.511 \\
Monthly family income & 0.57 & 0.571 \\
HS academic achievement & 0.72 & 0.472 \\
\hline
\end{tabular}

Note: his table presents a dprobit regression of employment status on various explanatory variables including family background as measured by monthly family income 


\section{Appendix 4}

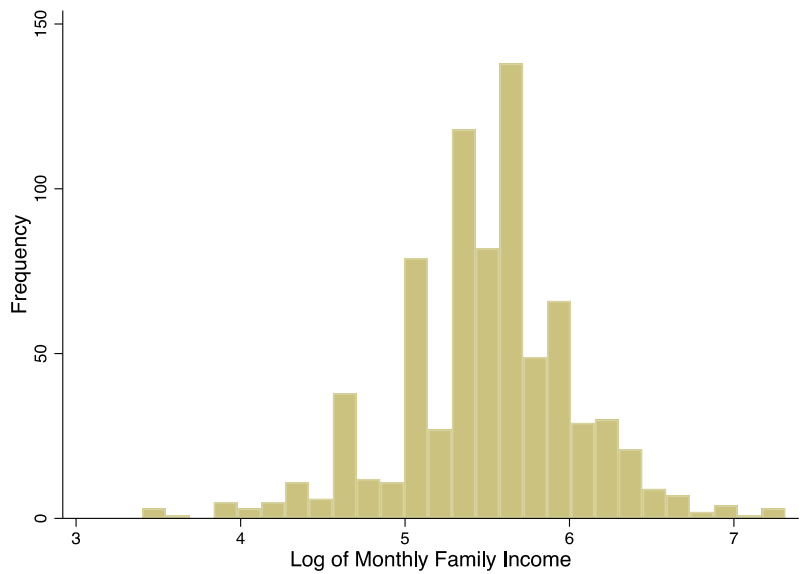

Fig. 2 Distribution of monthly family income

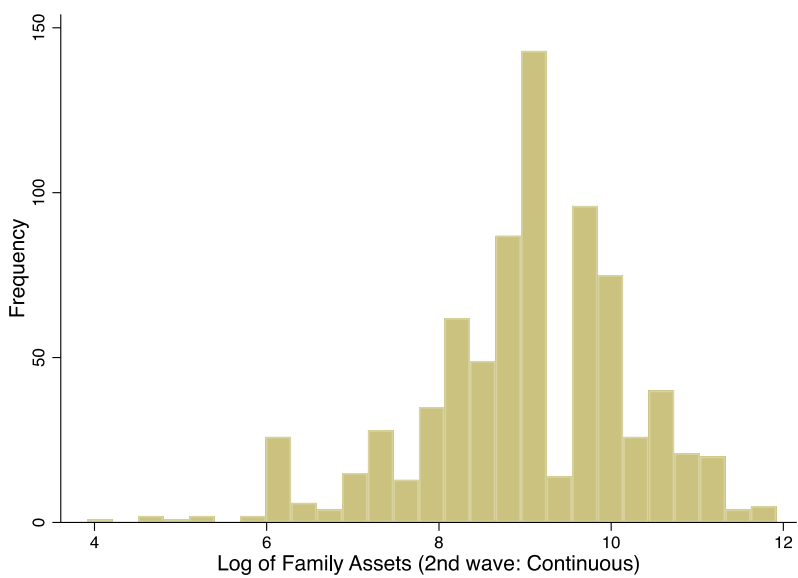

Fig. 3 Distribution of family assets imputed

Table 10

\begin{tabular}{llll}
\hline Father's education level & \multicolumn{2}{l}{ Summary of average monthly family income } & Freq. \\
\cline { 2 - 4 } & Mean & Std. Dev. & 275 \\
\hline Below middle school & 5.22 & .5431 & 549 \\
High school & 5.54 & .4620 & 65 \\
Two-year college & 5.76 & .4420 & 179 \\
Four-year college & 5.87 & .5176 & 43 \\
Postgraduate & 6.04 & .4146 & 1111 \\
\hline Total & 5.55 & .5418 & \\
\hline
\end{tabular}

Note: this table presents a cross tabulation for father's education level and the natural log of monthly family income 
Table 11

\begin{tabular}{llll}
\hline Father's education level & \multicolumn{2}{l}{ Summary of family assets } & \\
\cline { 2 - 4 } & Mean & Std. Dev. & Freq. \\
\hline Below middle school & 8.42 & 1.180 & 276 \\
High school & 9.11 & 1.063 & 560 \\
Two-year college & 9.39 & 1.026 & 64 \\
Four-year college & 9.78 & 1.095 & 183 \\
Postgraduate & 9.86 & 1.074 & 43 \\
$\quad$ Total & 9.09 & 1.189 & 1126 \\
\hline \multicolumn{1}{c}{} &
\end{tabular}

Note: this table presents a cross tabulation for father's education level and the natural log of family assets

Author contribution All authors whose names appear on the submission made substantial contributions to the conception or design of the work; or the acquisition, analysis, or interpretation of data; or the creation of new software used in the work; drafted the work or revised it critically for important intellectual content; approved the version to be published; and agree to be accountable for all aspects of the work in ensuring that questions related to the accuracy or integrity of any part of the work are appropriately investigated and resolved. Material preparation, data collection and analysis were performed by Sangwoo Lee and Anna Vignoles. All authors read and approved the final manuscript.

\section{Declarations}

Conflict of interest The authors declare no competing interests.

Open Access This article is licensed under a Creative Commons Attribution 4.0 International License, which permits use, sharing, adaptation, distribution and reproduction in any medium or format, as long as you give appropriate credit to the original author(s) and the source, provide a link to the Creative Commons licence, and indicate if changes were made. The images or other third party material in this article are included in the article's Creative Commons licence, unless indicated otherwise in a credit line to the material. If material is not included in the article's Creative Commons licence and your intended use is not permitted by statutory regulation or exceeds the permitted use, you will need to obtain permission directly from the copyright holder. To view a copy of this licence, visit http://creativecommons.org/licenses/by/4.0/.

\section{References}

Altonji, J. G., \& Dunn, T. A. (1996). The Effects of Family Characteristics on the Return to Education. The Review of Economics and Statistics, 78(4), 692-704.

An, J., \& Jeon, S. (2008). The intergenerational transmission of education and income level. The Korean Association of Public Finance, 1(1), 119-142.

Ashenfelter, O., \& Rouse, C. (1997). Income, Schooling, and Ability: Evidence from a New Sample of Identical Twins (Working Paper 6106; NBER Working Papers). National Bureau of Economic Research.

Britton, J., Dearden, L., Shephard, N., \& Vignoles, A. (2019). Is improving access to university enough? Socioeconomic gaps in the earnings of English graduates. Oxford Bulletin of Economics and Statistics, 81(2), $328-368$.

Byun, S., \& Park, H. (2017). When different types of education matter: effectively maintained inequality of educational opportunity in Korea. American Behavioral Scientist, 61(1), 94-113.

Chetty, R., Friedman, J. N., Saez, E., Turner, N., \& Yagan, D. (2017). Mobility report cards: the role of colleges in intergenerational mobility (Working Paper No. 23618). National Bureau of Economic Research.

Cho, Y. (2016). Higher education and social mobility in Korea - university-based meritocracy and duality of higher education effect. The SNU Journal of Education Research., 25(2), 1-20. 
Choi, P., \& Min, I. (2015). A study on social mobility across generations and inequality of opportunity. The Journal of Social Science, 22(3), 31-56.

Choi, Y., Lee, T., Hwang, J., Ma, K., Joo, J., Kim, E., Lee, H., \& Moon, H. (2016). Analysis on gender equality 2016 (No. 2016-96). Women's Development Institute.

Crawford, C., \& Erve, L. V. (2015). Does higher education level the playing field? Socio-economic differences in graduate earnings. Education in Science, 5(4), 380-412.

Crawford, C., \& Vignoles, A. (2014). Heterogeneity in graduate earnings by socio-economic background (IFS Working Paper W14/30). Institute for Fiscal Studies.

Han, D., Bae, K., \& Sohn, H. (2012). Estimating the university prestige effect in South Korea's labor market. KEDI Journal of Educational Policy; Seoul, 9(2).

Haveman, R. H., \& Smeeding, T. M. (2006). The role of higher education in social mobility. The Future of Children, 16(2), 125-150.

Hong, S. (2011). Female Employment Trend and Working Condition (Korean Social Trend 2011). Korean Women's Development Institute.

Hwang, I. (2018). Industry 4.0 and higher education quality improvement. Happiness and Education, Ministry of Education.

Jang, S. (1999). Inequality of educational opportunity. The Korean Sociological Association. 47-50.

Joo, L. (2018). Education and labor market outcomes in Korea. International Education Studies. 11(6).

Jung, J., \& Lee, S. (2016). Influence of university prestige on graduate wage and job satisfaction: The case of South Korea. Journal of Higher Education Policy and Management, 38(3), 297-315.

Jung, J., Yoo, J., \& Ha, J. (2019). Higher college enrollment rates for high school students in Seoul and even higher CSAT retake ratios. Joongang Daily.

Kang, S. (2009). Economic effects of education. Statistics Korea: Trends of Korean Society - Education. 77-82.

Kim, C., \& Oh, B. (2019). No gender discrimination before career disruption?: Gender earnings gap at the early stage of work career among college graduates in South Korea. Korean Journal of Sociology, 53(1), 167204.

Kim, H. (2014). Intergenerational mobility and the role of education in Korea. 45, KDI.

Kim, H., \& Voos, P. (2007). The Korean economic crisis and working women. Journal of Contemporary Asia, $37(2), 190-208$.

Kim, N. (2017). The wage gap among generations and between genders and implications thereof. Ewha Journal of Gender and Law, 9(2), 69-124.

Kim, S., \& Lee, J. (2006). Changing facets of Korean higher education: Market competition and the role of the state. Higher Education, 52, 557-587.

Korea Institute for Curriculum and Evaluation (2019). College Scholastic Ability Test. http://kice.re.kr/sub/info. do?m=0205\&s=english. Accessed 6 Jul 2020.

Korean Council for College Education (KCCE), (2019) An operational diagnosis of major intensive course of two-year colleges.

Korean Educational Statistics Service (2019). Education statistical analysis data: Higher education. https://kess. kedi.re.kr/eng/publ/publfile/pdfjs?survseq=2018\&menuseq=3895\&publseq=44\&menucd= 79977\&itemcode=02\&menuid=3_2_2\&language $=$. Accessed 24 Apr 2020.

Korean Higher Education Research Institute (2020). 2020 key higher education policies. Korean Higher Education Research Institute.

Korean Ministry of Education (2019). Basic Educational Statistics Results 2019. https://www.moe.go.kr/sn3hcv/ doc.html?fn=191d54b22d9127387a27f9f6fb523e0c\&rs=/upload/synap/202002/. Accessed 19 Jul 2020.

Korean Research Institute for Vocational Education \& Training (2021). Survey design. https://www.krivet.re.kr/ eng/eu/eg/euCBADs.jsp. Accessed 11 Dec 2020.

Kwon, H. (2018). Employment rates for females in the late 20 s and employment policy implications. Korea Employment Information Service Brief.

Lee, J. (2011). Economics for inequality. Humanitas.

Lee, J., Jeong, H., \& Hong, S. (2018). Human capital and development. Lessons and insights from Koreas transformation. Edward Elgar.

Lee, J., Jeong, H., \& Hong, S. (2014). Is Korea number one in human capital accumulation? Education bubble formation and its labour market evidence. (KDI School Working Paper 2014-03). Korea Development Institute.

Macmillan, M., Tyler, C., \& Vignoles, A. (2013). Who gets the top jobs? The role of family background and networks in recent graduates' access to high-status professions. Journal of Social Policy, 44, 483-515.

Monk-Turner, E., \& Turner, C. (2004). The gender wage gap in South Korea: How much has changed in 10 years? Journal of Asian Economics, 15(2), 415-424. 
Nam, K. (2008). The effect of parental education level on children's education and job status: International comparison analysis. The Education Finance and Economic Research, 17(1), 61-92.

Nam, Y., \& Huang, J. (2009). Equal opportunity for all? Parental economic resources and children's educational attainment. Children and Youth Services Review, 31(6), 625-634.

National Center for Education Statistics (2019). The condition of education: College enrolment rates. https://nces. ed.gov/programs/coe/indicator_cpb.asp. Accessed 5 Oct 2020.

Oh, M., \& Kim, J. (2011). Statistical analysis of private education expenses in Korea. The Korean Journal of Applied Statistics, 24(1), 193-206.

Oh, S. (2013). At least 2.5 million KRW, private tutoring for the CSAT Prep. Why parents invest in private tutoring. Chosun. https://www.chosun.com/site/data/html_dir/2013/07/10/2013071001680.html. Accessed 14 Jul 2020.

Oh, H., \& Chae, C. (2014). A comparative analysis of the initial labour market outcomes for two-year and fouryear college graduates in South Korea. Korea Employment Information Service Conference 2014, Labour Market Achievements II.

Organisation for Economic Cooperation and Development Data (2016). Educational attainment. Retrieved Aug 14, 2020, from https://data.oecd.org/eduatt/enrolment-rate.html

Organisation for Economic Cooperation and Development Data (2021). Gender wage gap (indicator).

Park, K. (2014). The college wage premium in Korea (1974-2011): A supply and demand factor decomposition. Review of Business and Economics, 27(1), 477-505.

Shin, K. (2011). The Gender Pay Gap in South Korea: Difference and Discrimination. Korean Journal of Sociology, 45(4), 97-127.

Statistics Korea. (2011). 2010 Expenditure on Private Education. Statistics Korea. http://kostat.go.kr/assist/ synap/preview/skin/doc.html?fn=synapview245342_5\&rs=/assist/synap/preview. Accessed 14 Jul 2020.

Statistics Korea. (2018). Economically Active Population in February 2018. Statistics Korea.

UK Department for Education (2019). Participation rates in higher education: Academic years 2006/2007 2017/2018.

Yeo, Y. (2008). A study of the influence of education on social mobility. Health and Social Welfare Review., 28(2), 53-80.

Yi, P. (2016). Time to degree of four-year university students in Korea. Korean Journal of Educational Administration, 34(5), 223-246.

Yi, Y., \& Kim, E. (2016). The college wage premium among the Korean youth. Quarterly Journal of Labor Policy, 16(3), 1-25.

Zhan, M., \& Sherraden, M. (2003). Assets, expectations, and children's educational achievement in femaleheaded households. Social Service Review, 77(2), 191-211.

Publisher's note Springer Nature remains neutral with regard to jurisdictional claims in published maps and institutional affiliations. 